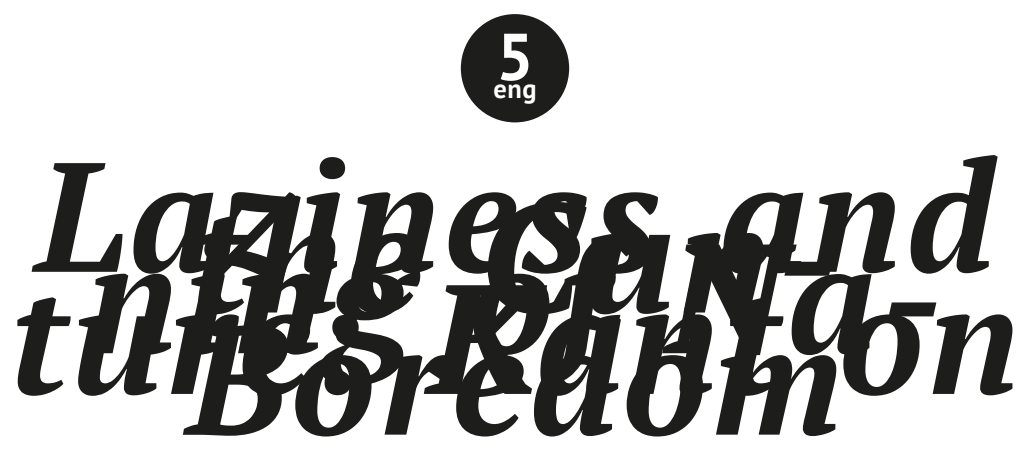

Dmitri Nikulin

Professor of Philosophy, Department of Philosophy,

New School for Social Research

79 Fifth Avenue, New York, NY 10003

E-mail:nikulind@newschool.edu

\title{
Laziness and the Cunning of Nature: Kant on Boredom
}

\begin{abstract}
The paper argues that boredom is a modern phenomenon and should be considered as the inalienable property or proprium of the modern lonely, universal, and tragic subject. As a token of radical inconstancy, imperfection, and fortuitousness, boredom, then, underlies our entire existence. In his Anthropology, Kant

undertakes an original attempt to rethink boredom as our propensity toward laziness, that is, the avoidance of tiresome and tedious activity, and thus toward rest. And yet, since absolute rest is tantamount to death, which causes aversion and fear, nature has put an opposite tendency in us, a kind of suffering and pain

that becomes the incentive to life-saving activity. Boredom, therefore, has to be considered a painful gift of nature that allows
\end{abstract}


us both to live on and live productively. In this respect, boredom is not only inevitable but also indispensable for our well-being, which, however, is understood from a perspective of the modern autonomous subject.

\section{Keywords:}

Boredom, modern subject, Kant, proprium, work, inclination, deception, nature

Modernity is a complex set of interacting and interwoven social, cultural, political, and historical processes and phenomena that establish, define, and describe our theoretical cognition, practical action, and productive activity. Among the concepts that determine it, perhaps the central and most significant is that of the modern subject, which is internalized by us and through which we perceive and construct our social, natural, political, and psychological reality. The modern subject establishes itself as universal, rational, necessary, and understands itself as self-defined by (excessive) reflexivity and self-awareness. Being a historical (self-)construction, it considers itself as its own transhistorical achievement in history, which is ultimately produced by itself. Most importantly, the modern subject realizes itself as autonomous, as self-legislating and self-sufficient, uniquely asserting a normatively binding moral law, which is meant to be universalized and appropriated by each individual. And yet, such a subject makes the otherness of others only a task to be achieved, and in this way renders interlocutors redundant in theoretical investigation and practical action.

In this way, the modern subject releases itself from the bond of others. It is always a singular collective without and outside of plurality. Exclusive of others, the modern subject is the only actor in and of the theoretical, practical, and productive drama of modernity, being its protagonist, playwright, director, and spectator at the same time. In the absence of others, the modern subject is utterly lonely, solitary, and monological in its being and thought. Hence, it is inevitably bored.

The philosophical study of boredom, therefore, is also a critique of the concept of the modern subject as the realization of universal reason in its transformations and vicissitudes ${ }^{1}$.

1 Among the considerable contemporary literature on boredom the most important contributions that also discuss the significance of boredom after Kant in literature, film, and philosophy (primarily, in Simmel, Heidegger and Benjamin) are Toohey (2011), Goodstein (2005), Svendsen (2005), and Healy (1984). 
Being very familiar, boredom is utterly unfamiliar. Boredom is an evasive concept and is thus difficult to grasp, inquire into, and understand what the proper question might be, which is why it comes under a different name even in closely related languages (tédio, noia, aburrimiento). One might make a distinction between passion as a natural physiological phenomenon experienced by all humans at all times, and emotion as a culturally processed and trained passion. While the basic or universal passions might be relatively few, a number of emotions, such as saudade or toska (тоска), are culturally specific and are difficult to translate and render precisely into a different cultural context. Yet my claim is that boredom is neither a universal passion, nor a mental state, nor a psychological emotion but rather the inalienable proprium or iosov of the modern subject, which nevertheless does not define the subject in its essence, since the modern subject does not have an essence beyond what it freely and autonomously assigns to itself. Rather, boredom is the "idiotic" proper without which the subject cannot be thought and with which it is mutually substitutable. Paraphrasing Aristotle, one can say: if modern subject, bored; if bored, modern subject. In this sense, boredom constitutes the very conditio moderna.

\section{The Long While}

In modernity, Immanuel Kant is not only one of its most remarkable systematic thinkers but also the one who, despite being deeply rooted in the tradition of scholastic thinking, epitomizes the main historical features of modern philosophy. Somewhat simplifying, one could say that modern subjectivity finds its theoretical expression in Descartes, while practically-in Kant.

Discussing the feeling of pleasure and displeasure in his Anthropology from a Pragmatic Point of View (2007), Kant dedicates an entire section to the consideration of boredom and its role in human life. The section is called "On Boredom and Entertainment," which is a linguistic opposition between "long while" (lange Weile, or "boredom") and "short while" (Kurzweil, or "amusement") (Kant 7:233-43). Boredom for Kant is aversion or repugnance to one's own existence (die Anekelung seiner eigenen Existenz) (Kant 7: 151). This existence is not being as such, but rather being that is devoid of any content, insofar as it faces no change. It is empty being or pure negativity. To be sure, being is that which does not or should not change, as opposed to becoming. Yet the human being is the being that lives, is alive and as such seeks a change that comes from the world in the form of 
perception, providing for a possibility of life, knowledge, and experience. We thus constantly strive toward, and need, new impressions or perceptions; we otherwise feel the dull pain of boredom, which thus arises from the emptiness of the soul, destitute of perceptions (aus der Leerheit des Gemüts an Empfindungen) (Kant 7:151). Boredom is therefore a response to the lack of impressions, to the absence of any signs or greeting from the world, of its frightening silence that leaves us in panic and the anticipation of death.

One should note that before Kant, Johann Georg Sulzer suggested that boredom is a painful mood of the soul that awakens a "mortal annoyance" (ein tödlicher Verdruß), which we cannot get rid of and which arises from the impeding inactivity (Unthätigkeit) of our soul that constantly searches for new thoughts and impressions. And yet, boredom contributes to our happiness, to the extent that happiness has to be earned and cannot be enjoyed without first going through suffering and negative states (Sulzer 1773: 21).

One might thus say that boredom is akin to sensory deprivation. When people are exposed to sensory deprivation, they often start to hallucinate, thus attempting to compensate for the loss of external (sensory) and internal (thinking as self-perception) impressions. Philosophically, this response is explored by Al Farabi in the "flying man" and by Descartes in the "cogito" arguments, which intend to show that the suspension or ultimate lack of sensory input leads to the realization of thinking as a reflective act of thought that has nothing else to think except for itself. Perhaps our dreams are just similar responses to temporary sensory deprivation, when we start producing images in order to cope with the nothing as always the same response from the world.

The fright (Grauen) of the everlasting sameness without any difference or novelty or the possibility of transformation is similar to the horror of emptiness (horror vacui) (Kant 7:233), of the emptiness that has no distinctions or divisions, and is the triumph of the coincidence of the identical with the non-identical. For the lack (of perception)

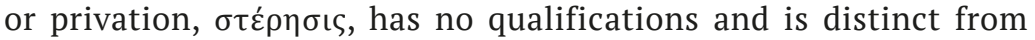
anything definite, and yet at the same time cannot be distinguished from anything, because it is a pure negativity or nothing, a not-this and never-yet. Nothing cannot even cause anxiety, because anxiety is the fear of something whose cause we cannot understand. But nothing as privation is not a cause-or only accidentally. The horror of non-being is the dread of death, and boredom is its sign.

Life, on the contrary, is a constant renewal-of perception and thought, an incessant leaving of a given state (Kant 7:233). Life is 


\section{Dmitri Nikulin}

the continuous abandonment of sameness that intends to preserve itself as sameness. Life is the assertion of oneness through a multiplicity of otherness that can never stop self-reproducing. The stop is a break that becomes the condition of the impossibility of the continuation of thought and the motion of perception. Boredom, then, is the unmediated pre-reflective pain that is the indication of the possibility of such a rupture.

\section{Double Move at Self-preservation}

Yet the constant change and motion of renewal and the flux of new perceptions and impressions can be unsettling, annoying, and destructive. Here, Kant shares, probably without realizing it, the fundamental Stoic thought that nature has equipped us with means for self-preservation-caritas sui or $\dot{\varepsilon} \pi \iota \varepsilon^{\prime} \lambda \varepsilon\llcorner\alpha \dot{\varepsilon} \alpha \cup \tau o \tilde{v}$-of each other and of the polis as the commonality that preserves our being together with others ${ }^{2}$. Cicero tells us that from the very moment a living being is born, it "feels an attachment for itself, and a tendency to preserve itself and to feel affection for its current state and for those things which tend to preserve that state; while it moves away from destruction and from those things which appear to contribute to destruction" (Cicero 1914: 232, author's own translation) ${ }^{3}$. Boethius, influenced by Stoics in his moral philosophy, maintains in The Consolation of Philosophy (1973) that all living-and thus mortal-things exemplify a "care for themselves" (sui caritas) which comes from an "exertion of nature" (ex naturali intentione); therefore, all things "seek naturally the continuance of their own survival, and avoid destruction" (Boethius 1973: 294-95, quae sunt appetere naturaliter constantiam permanendi, devitare perniciem)

Yet this striving at preserving ourselves is double and ambiguous, in that it balances two opposite moves. On the one hand, we have a propensity to laziness, avoidance of tiresome and difficult activity and thus toward rest (Neigung zur Gemächlichkeit; Ruhe) (Kant 7: 151). However, absolute rest is death, which causes aversion (Ekel) and fear.

2 Cf. Diogenes Laertius (1925: 88); Dio Chrysostom (1946: 246-8).

3 "Simul atque natum sit animal [...] ipsum sibi conciliari et commendari ad se conservandum et ad suum statum eaque quae conservantia sunt eius status diligenda, alienari autem ab interitu iisque rebus quae interitum videantur afferre" (Cicero 1914: 232). Cf. Seneca, who speaks about a "natural love for self-preservation" (Seneca 1925: 408 , naturali amore salutis suae, author's own translation) and about "the first tool that the nature granted them [living beings] for their preservation, self-attachment and self-care" (Ibid.: 410, Primum hoc instrumentum in illa natura contulit ad permanendum, conciliationem et caritatem sui, author's own translation). 
Nature thus has put an opposite tendency in us, which echoes the fear of nothingness, of sameness without otherness, through a kind of suffering and pain, which is the incentive to life-saving activity (den Schmerz zum Stachel der Tätigkeit) (Kant 7: 235). Boredom calls us to make explicit something that bothers us without realizing what is it that bothers us. Boredom is thus a painful gift of nature that allows us both to live on and eventually to live well.

For Kant, by nature we are inclined to be lazy and keep at rest-and to suffer for it. The careful, constant balancing between the sameness of rest and the otherness of motion is what constitutes life in its suffering and enjoyment, in all its misery and glory. The cunning of nature is then meant to preserve us through the negativity of suffering, which is not accidental or meaningless but has the purpose of the renewal of our mental, physical, and even social life. Discussing the idea of history in which we all participate and which we cannot escape, Kant introduces the famous notion of "social unsociability" (Kant 8: 20, die ungesellige Geselligkeit german phrase in italics). This idea as developed by Kant is similar to that of Bernard de Mandeville (1989), who argued that the negativity of private striving and egoistic interest does inevitably contribute to the public good. Kant claims that the highest purpose of nature, which is the development of all our natural capacities to the highest degree, can be achieved by means of what nature has supplied us with care yet without our choice or consent, namely, by social antagonism or "social unsociability." Similarly to boredom, social antagonism is based on opposing tendencies (the tendency to live in a society with others yet live as an individual in isolation) and to overcome the human "tendency for laziness" (Kant 8: 21, Hang zur Faulheit). Nature's nurturing slyness thus comes with a propensity that we find in ourselves that embraces opposites and perpetuates conflict and is meant to bring us, by nudging and forcing through struggle and fear, out of the natural state of rest toward the activity of life. Life is thus sustained and preserved as individual solitary activity through the pain of boredom, and as commonly shared social activity through unsocial sociability.

\section{Work and Boredom}

Boredom is thus an indication of the inertia and dullness (Trägheit) of existence, of the satiation of any activity (Überdruss an aller Beschäftigung) (Kant 7: 151). But the most important intentional activity proper to humans for Kant is work. Modernity understands the human being primarily as a homo faber. Work is difficult and painful yet a 


\section{Dmitri Nikulin}

necessary and unavoidable life-preserving activity. Everything important in life in the Kantian autonomous and production-oriented social world comes through work; human dignity, worth, and political standing are defined by the how and what of work as one's own work: produced, alienated, and appropriated once again. Idleness amounts to laziness and as such is morally reprehensible, and enjoyment and rest can only be justified as a deserved prize ${ }^{4}$. In order to have the right to moral satisfaction and pleasure in life, one has first to toil and suffer. Boredom, then, prompts us to act: it is a great motivational force. The entire modern morality is based on the idea of the morality of work and the inevitability of suffering that we need to go through in order to fulfill our duty. According to this approach, I do something even (and mostly) if I do not want to do it, but I still do it out of the unqualified sense of duty. The opposite teleological moral position suggests that I do something because I want to achieve a particular end, and I do so often because I enjoy the action as interaction with others.

Kant's moralistic pedagogical appeal to the youth is to love and embrace work and renounce pleasure, not to abdicate from pleasure altogether but to postpone it and have it ahead of you, in the hope of achieving enjoyment as a goal of work: "Young man! (I repeat) get fond of work; deny yourself enjoyments, not to renounce them, but rather to keep them always in perspective as far as possible! Do not dull your receptivity to enjoyments by savoring them prematurely! The maturity of age, which never lets us regret having done without a single physical enjoyment, will guarantee, even in this sacrifice, a capital of contentment which is independent of either chance or the laws of nature" (Kant 7:237; 2007:340). This is already the maxim of a teleological action, which, however, is not autonomous, because it is defined not by our practical reason and its imperative, and because it posits a means to an end that is not contained in the activity or the lack of it. But most importantly, pleasure now becomes a capital that we need to accumulate and grow with interest, in order to savor it at retirement! And those who did not work or accumulate this capital apparently will not be entitled to pleasure.

Boredom is thus a force or impulse put into us by nature, an inevitable yet potentially beneficial force of suffering, which is not rational but sensible and whose purpose is to avoid the immobility of stagnation and the lack of new perceptions. Boredom motivates us to work more. And if people try to overcome the dullness of work by

${ }^{4}$ For a critique of the modern paradigm of production that alone is supposed to establish human dignity and in defense of idleness as freedom see O'Connor (2018: 3-11, 163-76). 
trying to find pleasure in their work, they still, as Friedrich Nietzsche puts it, "do not fear boredom as much as work without pleasure; they actually require a lot of boredom if their work is to succeed" (1974: 108). While being painful, boredom allows for postponing fantasies and anticipated pleasure that will come with the enjoyment of new impressions and perceptions. In this sense, boredom and work are similar but are also distinct: they are similar in that both are a form of negativity that impels us to act and thus enjoy life as the result of necessary suffering (Kant 7:232) ${ }^{5}$. Yet they are also different in that work is a positive form of suffering that comes with a plan and project of the anticipated result to be enjoyed. Boredom, on the contrary, is a negative form of suffering, indicative of the lack of perceptions of an empty soul that does not yet know what to enjoy.

But is thinking, then, a toil or enjoyment? If it is work and is a means to achieve an end, it should be difficult and unpleasant and only be needed when we have to produce something-a conclusion of an argument, a solution to a problem, or a new item of knowledge. Such thinking is inevitably painful and boring. Kant (7:234) clearly opts for thinking as hard, productive work, from which we have a chance to obtain rest, and which produces not only theoretical novelty but also rejuvenates our will and generates a morally upright, reasoned action. But if thinking is pleasure, it can testify to the joy of being. Such thinking is engaging, enjoyable, and as Alfred North Whitehead (1974: 259) suggests, is interesting before it is true. (Whitehead's proposition is itself interesting, although it might not be true.) But in order for thinking to be enjoyable and not boring, it should be practiced and shared with others as a non-productive activity in which the capital of joy is never accumulated but is always spent with others at the very moment it appears.

\section{Opposing Inclinations}

Thus, in order to live the good life, we need to legitimately earn to enjoy it. For Kant (7:233), life and enjoyment are closely related, since in order to enjoy life, one must perceive it in its constant change and abandoning of the current state. However, in order to be legitimate and acceptable, enjoyment, which always depends on accidental circumstances that are beyond our control, must follow the (moral)

${ }^{5}$ Kant (7: 232) compares the enjoyment that comes as the result of initial unpleasantness and suffering to smoking, when the early irritation the body experiences results in the pleasure of new perceptions and even thoughts, even if such thoughts might be only fleeting. 


\section{Dmitri Nikulin}

purposes that we establish and pursue (Ibid.: 237-38). At this point, Kant is a Stoic thinker who carefully distinguishes between what is up to us what is not, between what we can properly choose and what we cannot (Epictetus 1925: 206-25).

Kant is even more Stoic when he claims-which comes as a postulate that makes the good, enjoyable life possible-that nature has put certain impulses into us. The purpose of these impulses or inclinations minimally is to preserve life, and maximally to maintain a good, enjoyable, and socially shared life. To this end, nature has equipped us with opposite impulses: one toward rest, which preserves sameness through not-acting (laziness), and the other toward change, which keeps otherness and change through negation, suffering, and contentious action (boredom and unsocial sociability). We should surmise a (or even the) purpose of the impulse: it is an indication that something is going wrong in our life, and thus we should move elsewhere, toward a better life envisaged for us by nature. The good life, then, is a carefully maintained balance of sameness and otherness, which is never a given or guaranteed but must be sought and kept each time anew and in a concrete situation of human interaction.

The life-preserving impulse cannot be chosen by us, because it is an inclination or propensity, Hang, which shows that the very foundation of our life is uneven, skewed, and slanted unless it is leveled and rectified by morally upright reason ${ }^{6}$. Moreover, such an impulse is not rational and is thus hardly controllable, yet is clearly detectable in its working through (negative) action. Only then can the natural impulse in us become the subject of philosophical reflection. The beginning of philosophy, on such interpretation, is not the wonder of being but the realization of one's weakness and limitation ${ }^{7}$. The working of impulse is negative (the inertia of rest or the dull pain of boredom) but the result of its interaction with its opposite is, or should be, positive, producing the enjoyable and continuing life as the synthesis of sameness and otherness.

\section{The Art of Deception}

Yet there is another inclination or impulse that we need to recognize when we analyze our life stung by boredom: it is the incli-

${ }^{6}$ Cf. Kant (1914a: 28-32). For an English translation, see Kant (1996: 76-79).

7 Cf. Epictetus (1925: 276): "The beginning of philosophy [...] is the consciousness of one's weakness and impotence in the face of those things that are necessary and

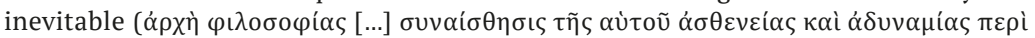
$\tau \grave{\alpha} \alpha \dot{\alpha} v \gamma \kappa \kappa \tilde{\tau} \alpha)$ (author's own translation)." 
nation to be willingly deceived (Kant 7: 151-52). Kant is very strict and upright about mendacity, which for him is the condition of the impossibility of human interaction. The maxim "You should not lie" is the main prescription and the cornerstone of philosophy for him, so that eventually it will secure the eternal peace and flourishing of humankind ${ }^{8}$. The presupposition of a simple and straightforward correspondence between (physical and moral) reality and the truth about it as reflected in cognition and moral action is a fundamental basis of the modern attitude toward the world and oneself as an embodiment of a universal subject who establishes the truth by, through, and from within oneself. In order to be identical with, and thus truthful to, oneself, one needs to produce and recognize the truth that would be exactly as one produces and recognizes it. In its identity and sameness, the subject cannot and should not lie or deceive oneself. One can be mistaken or deceived, yet intentional mendacity has to be ruled out, because it upsets the order of moral communication by undermining, and morally and cognitively eliminating, the subject who sets the moral and social relations in the first place.

Mendacity, then, is lying with the intention to deceive the other without the other knowing it. For Kant, one may be mistaken (irren), but one should never lie (lügen, täuschen) (Kant 8: 421-22). However, as said, nature has endowed us with the inclination to be willingly deceived. Therefore, it is acceptable to deceive (betrügen) when the deception is morally permissible and stays within the accepted moral limits (Kant 7:152). Since the natural sensible inclination or impulse (toward rest and not-acting) is an obstacle to life and thus to the good life (for there can be no good life without life), one needs to act against this inclination. One way to do it is, as said, by work. Yet work is difficult and is a positive suffering toward an end. The other way to confront the inclination is by deceiving it. For nothing can be gained against sensible and sensual inclinations by force or sheer decision. Therefore, it is permissible to fight the enemy of our well-being by its own means: to deceive the deceiver (Ibid.: 152, den Betrüger... zu betrügen). Here, the natural inclination to be deceived counters the inclination toward idling. In this way, boredom too can be deceived.

Kant apparently takes the deception of the deceiver not to be itself a natural inclination in us. Therefore, it should come as an

8 "Das Gebot: du sollst... nicht lügen, zum Grundsatz in die Philosophie als eine Weisheitslehre innigst aufgenommen, würde allein den ewigen Frieden in ihr nicht nur bewirken, sondern auch in alle Zukunft sichern können” (Kant 8: 422). 


\section{Dmitri Nikulin}

artificial and artful device that needs to be and can be cultivated, organized, and properly presented. In particular, we are amused when (1) we know that we are deceived; (2) that the deceiver knows that we are deceived; and (3) that the deceiver knows that we know that we are deceived. If these three conditions are met, we enjoy the deception and call it fine art (schöne Kunst). Art is deception. However, it is the deception that does not lie but tells the truth about the world and ourselves by deceiving, that is, by presenting the fiction of things and actions, not the way they are or have been, but the way they might or should have been ${ }^{9}$. One should thus overcome the cunning of nature by the cunning of art, not by replicating or imitating nature-but by deceiving it. The art of modern subjectivity is, therefore, not the art according to nature but contrary to nature and its impulses.

The most socially acceptable and morally significant form of art is the one that, although played in the "as if" mode and often in imagination, is closer to the real life of suffering, enjoyment, and communication. This is theater. Hence, the more cultivated people are, the more they are actors for Kant (Ibid.: 151). Contemporary psychological observations suggest that people tend to deceive more often and more willingly if they cooperate with others (Weisel and Shalvi 2016), which might be construed as cooperation in a theatrically shared setting. Dramatic art is the art of showing people's interactions not the way they happened but the way they might have been. Therefore, an actor is a professional pretender, deceiver, and hypocrite, and hypocritēs is an actor. As we know from François de La Rochefoucauld, hypocrisy is the homage that vice pays to virtue ${ }^{10}$. Yet the hypocrisy in theater is an intended pretense and deception that is understood and valued as such by both actors and spectators.

However, on the stage of public life we need to perform and impersonate socially acceptable roles, which is why we should wear good manners, decorum, and politeness. The appearance of the good might seem pretentious and insignificant, a kind of small coin (Kant 7: 152), which can buy much and which has been in circulation for so long that its devices have been obliterated almost to the point of being unreadable. But even a habitual appearance of the good in other people should be valuable. Such theatrical, hypocritical acting is only a semblance of proper morality, yet it is permissible and in fact necessary, because it leads to the seemingly

9 Cf. Aristotle (1995: 58-59).

10 "L'hypocrisie est un hommage que le vice rend à la vertu" (La Rochefoucauld 1964: maxime 218). 
deceptive and hypocritical but eventually habitual establishment and promotion of good morals. We fend off the pain of boredom by an aimless play (zweckloses Spiel) that nevertheless has a purpose, that of entertaining the immobile and immobilized bored mind of work and moral action. The purposeless game comes with the joy of play and thus contributes to the culture of the soul and the cultivation of morals (Kultur des Gemüts) (Kant 7: 152). As Kant claims in The Metaphysics of Morals (1914b: 473), our duty to both ourselves and others is to contribute to the appearance of virtue in public through manners, politeness, and culture, by affecting each other through our moral qualities and sociability (officium commercii, sociabilitas), by acting with others and not separating from them, by cultivating tolerance and friendliness, and by the display of humanness and propriety (humanitas aesthetica et decorum) ${ }^{11}$. The paradigm of such socially entertaining art is theater, because drama allows us to witness life-like informative experiences and new perceptions, which drive away the "long while" of boredom by the "short while" of amusement and thus contribute to the renewal of life. The enjoyment of theater comes from the possibility of empathizing with the actors yet feeling lucky not to be in the same predicament (Kant 7:238-39). This is tragedy. But when one rejoices with others and learns from them how to solve seemingly unsolvable social puzzles and to untangle apparently irresolvable situations through a common effort, this is comedy. Boredom, then, is a negative mediator between work as positive suffering, difficult and painful striving toward the best, which is tragedy-and culture as pleasurable entertainment and purposeless play that still has the purpose of the rejuvenation of life, which is comedy. If this is the case and if culture can be taken as the means of increasing our capacity for even greater enjoyment through the deception of art (Ibid.: 236), then culture can be defined as the socially and morally acceptable way of regulating boredom.

\section{Boredom unto Death}

In the theater of moral and social life, wearing the mask of good morals becomes a form of action, and the appearance becomes indistinguishable from the essence of a good life. But the modern moralistic subject can, and should, entirely erase the difference

11 Contrary to his argument in the Anthropology, however, in The Metaphysics of Morals Kant claims that the appearance of virtue does not deceive (nicht betrügt). 


\section{Dmitri Nikulin}

between the appearance of the good and the morally good as such only in oneself. The acting should stop in front of the lonely, stern gaze of oneself as one's own spectator, judge, and inquisitor, because the appearance and play here can only veil one's egotism, cover for moral trespassing-and even make one believe that one can redeem one's guilt, the source of an irredeemable anxiety (Kant 7: 153) ${ }^{12}$.

This means that the ultimate coincidence of the good and the appearance of the good is death, in which no further action of the subject toward itself is possible or required. Boredom, then, is the death of the subject who is still alive but does not want to live on. This is why in his anthropology lectures Kant exclaims in desperation: "Boredom is the disgust that one has for a condition in which one finds oneself. It is the great ill and the cause of much evil" (25: $1336 ; 2012: 441)$. Yet, since death is the ceasing of any activity of life (7:235), one strives toward life, which, as said, is a constant renewal, the life of action, change, novelty in perception and thought, and interaction with others. Since the solitary and lonely monological subject strives toward life, it wants to avoid the death of ultimate solitude and self-reliance, and thus to get rid of itself, or commit suicide. Since the life of the solitary modern subject is boredom, the lack of life, it implies its own abandonment.

Extreme boredom thus can cause suicide ${ }^{13}$. The modern philosophical subject is fascinated with death and seeks to get rid of itself, in order to make way for life as renewal and novelty. The lonely subject attempts to commit a philosophical suicide out of the sense of inescapable boredom, trying to achieve its death by various philosophical devices-by the "death of the author," intersubjectivity, fragmentation, "automatic writing," intertextuality, transindividuality, etc. (Nikulin 2010: xii-xiii) ${ }^{14}$. And yet, the modern subject cannot succeed in killing itself, wiping itself out as morally corrupt and guilty, forever remaining its own predicament and unintended destiny, only protracting the inevitable and unredeemable lonely suffering, the boredom of the same inevitably encountering the same ${ }^{15}$. The severe and ruthless judge of one's own conscience cannot allow for this: the monological, moralistic modern subject is not redeemable in its solitude. It is utterly serious and thus does

${ }^{12}$ Cf. Klein (1994: 86-90): One educates oneself about the meaning of words (e. g., fame) in a lonely Stoic-kind of discourse with oneself directed to oneself.

${ }^{13}$ Cf. Kant (7: 233): "[T]he Englishmen hang themselves, just to pass the time."

${ }^{14}$ Cf. Balibar (1997: 3-36).

15 "Boredom removes everything, even the courage to kill himself" (Stendhal 1947: 267). 
not, should not, and cannot enjoy the engaging play in the theater of public life.

\section{References}

Aristotle (1995). Poetics. Trans. Stephen Halliwell. Cambridge, MA: Harvard University Press.

Balibar, Étienne (1997). Spinoza: From Individuality to Transindividuality. Delft: Eburon.

Boethius (1973). The Consolation of Philosophy. Trans. H. F. Stewart, E. K. Rand, and S. J. Tester. Cambridge, MA: Harvard University Press.

Cicero (1914). On Ends. Trans. H. Rackham. Cambridge, MA: Harvard University Press. de Mandeville, Bernard (1989). The Fable of Bees, or Private Vices, Publick Benefits. London: Penguin.

Dio Chrysostom (1946). Discourses 37-60. Trans. H. Lamar Crosby. Cambridge, MA: Harvard University Press.

Diogenes Laertius (1925). Lives of Eminent Philosophers Vol. 2. Trans. R. D. Hicks. Cambridge, MA: Harvard University Press.

Epictetus (1925). Discourses: Book I and II. Trans. W. A. Oldfather. Cambridge, MA: Harvard University Press.

Goodstein, Elizabeth S. (2005). Experience without Qualities: Boredom and Modernity. Stanford: Stanford University Press.

Healy, Seán Desmond (1984). Boredom, Self, and Culture. Rutherford, NJ: Fairleigh Dickinson University Press.

Kant, Immanuel (1914a). "Die Religion innerhalb der Grenzen der blossen Vernunft," ed. Georg Wobbermin. In Gesammelte Schriften, Vol. 6, ed. Prussian Academy of Sciences, 3-202. Berlin: De Gruyter.

Kant, Immanuel (1914b). “Die Metaphysik der Sitten,” ed. Paul Natorp. In Gesammelte Schriften, Vol 6, ed. Prussian Academy of the Sciences, 205-493. Berlin: De Gruyter.

Kant, Immanuel (1917). "Anthropologie in pramatischer Hinsicht," ed. Oswald Külpe. In Gesammelte Schriften, Vol. 7, ed. Prussian Academy of the Sciences, 117-334. Berlin: De Gruyter.

Kant, Immanuel (1923). "Idee zu einer allgemeinen Geschichte in weltbürgerlicher Absicht,” ed. Heinrich Maier. In Gesammelte Schriften, Vol. 8, ed. Prussian Academy of Sciences, 15-31. Berlin: De Gruyter.

Kant, Immanuel (1923). "Verkündigung des nahen Abschlusses eines Traktats zum ewigen Frieden in der Philosophie," ed. Heinrich Maier. In Gesammelte Schriften Vol. 8, ed. Prussian Academy of the Sciences, 413-22. Berlin: De Gruyter.

Kant, Immanuel (1991). "Idea for Universal History with a Cosmopolitan Purpose," trans. H. B. Nisbet. In Political Writings, ed. Hans Reiss, 41-53. Cambridge: Cambridge University Press.

Kant, Immanuel (1996). "Religion within the Bounds of Mere Reason," trans. George di Giovanni. In Religion and Rational Theology, ed. Allen W. Wood and George di Giovanni, 39-216. Cambridge: Cambridge University Press.

Kant, Immanuel (1998). “Anthropologie Mrongovius.” In Gesammelte Schriften, Vol. 25, ed. Academy of the Sciences of Göttingen, 1209-429. Berlin: De Gruyter.

Kant, Immanuel (2007). “Anthropology from a Pragmatic Point of View," trans. Robert B. Louden. In Anthropology, History and Education, ed. Günther Zöller and Robert B. Louden, 227-429. Cambridge: Cambridge University Press.

Kant, Immanuel (2012). “Anthropology Mrongovius,” trans. Robert R. Clewis. In Lectures on Anthropology, ed. Allen W. Wood and Robert B. Louden, 335-510. Cambridge: Cambridge University Press. 


\section{Dmitri Nikulin}

Klein, Lawrence Eliot (1994). Shaftesbury and the Culture of Politeness: Moral Discourse and Cultural Politics in Early Eighteenth-Century Europe. Cambridge: Cambridge University Press.

La Rochefoucauld, François de (1964). “Maximes.” In Oeuvres complètes de La Rochefoucauld, ed. Louis Martin-Chauffier, 293-498. Paris: Gallimard.

Nietzsche, Friedrich (1974). The Gay Science. Trans. Walter Kaufmann. New York: Vintage.

Nikulin, Dmitri (2010). Dialectic and Dialogue. Stanford: Stanford University Press.

O'Connor, Brian (2018). Idleness: A Philosophical Essay. Princeton: Princeton University Press.

Seneca (1925). Epistles Vol. 3. Trans. Richard M. Gummere. Cambridge, MA: Harvard University Press.

Stendhal (1947). Love. Trans. H. B. V. New York: Liveright.

Sulzer, Johann Georg (1773). "Untersuchungen über gen Ursprung der angenehmen und unangenehmen Empfindungen.” In Vermischte philosophische Schriften, Vol. 1, 1-98. Leipzig: Weidmann.

Svendsen, Lars (2005). A Philosophy of Boredom. Trans. John Irons. London: Reaktion Books.

Toohey, Peter (2011). Boredom: A Lively History. New Haven, CT: Yale University Press.

Weisel, Ori, and Shaul Shalvi (2016). "The Cooperative Roots of Corruption." Proceedings of the National Academy of Sciences. http://www.pnas.org/content/112/34/10651.full

Whitehead, Alfred North (1974). Process and Reality. Ed. David Ray Griffin and Donald W. Sherburne. New York: Free Press. 